\title{
In Vitro and In Vivo Refractoriness to Thyrotropin Stimulation of Iodine
}

\section{Organification and Thyroid Hormone Secretion}

\author{
James B. Field, Andrew Dekker, Gail Titus, Mary Eleanor Kerins, \\ William WORDEN, and ROSAlYN Frumess, Clinical Research Unit and \\ Department of Medicine and Pathology, University of Pittsburgh School of \\ Medicine, Pittsburgh, Pennsylvania 15261; The Diabetes Research Laboratory \\ of St. Luke's Hospital, Baylor College of Medicine, Houston, Texas 77025
}

\begin{abstract}
A B S T RACT Earlier studies indicated that initial exposure of thyroid slices to thyrotropin diminished responsiveness of the adenylate cyclase-cyclic AMP system, glucose oxidation, and ${ }^{32} \mathrm{P}_{\mathrm{i}}$ incorporation into phospholipids upon readdition of the hormone. The present studies demonstrate that slices from dog, beef, and human thyroid glands initially incubated with thyrotropin (TSH) were less responsive to subsequent addition of the hormone when organification of iodide was examined. Increasing the amount of TSH did not overcome the refractoriness induced by the initial exposure to the hormone. Furthermore, the stimulatory effects of dibutyryl cyclic AMP and prostagladin $\mathrm{E}_{1}$ were abolished in slices previously incubated with TSH. Development of such refractoriness did not depend upon new protein synthesis and was not abolished by $1 \mathrm{mM}$ prophylthiouracil in the first incubation. Addition of $0.1 \mu \mathrm{M}$ thyroxine or triiodothyronine or $1.5 \mu \mathrm{M}$ iodide during all three incubations did not modify the response to TSH, added for the first time in the third incubation. However, $1 \mathrm{mM}$ iodide in the buffer during all three incubations inhibited the response to TSH during the third incubation. During the refractory period, effects of TSH on colloid droplet formation were also diminished. The in vivo effect of TSH on serum $l$ - triiodothyronine in rats was significantly reduced when the rats had been injected with TSH $8 \mathrm{~h}$ earlier. These studies demonstrate that TSH-induced refractoriness also includes effects on organification of iodine and secretion of thyroid hormone. The results cannot be adequately explained by unresponsiveness of adenylate cyclase because effects of dibutyryl cyclic AMP and prostagladin $\mathrm{E}_{1}$ were also inhibited by prior exposure to TSH.
\end{abstract}

Received for publication 3 October 1977 and in revised form 7 February 1979.

\section{INTRODUCTION}

An initial incubation of thyroid tissue with thyroidstimulating hormone $(\mathrm{TSH})^{1}$ significantly diminished the stimulation of the adenylate cyclase-cyclic AMP system induced by readdition of the hormone (1-5). Furthermore, effects of TSH on glucose oxidation and ${ }^{32} \mathrm{P}_{\mathrm{i}}$ incorporation into phospholipids were also decreased during the refractory period (6). Such refractoriness was not associated with reduction in binding of TSH $(5,6)$. Although adenylate cyclase activity in homogenates was insensitive to stimulation by TSH during the refractory period, this could not account for the entire phenomenon because effects of dibutyryl cyclic AMP (DBC) on glucose oxidation and acetylcholine on ${ }^{32} \mathrm{P}_{\mathrm{i}}$ incorporation into phospholipids were also diminished (6). DBC would be expected to replace endogenous cyclic AMP and effects of acetylcholine are not mediated via the adenylate cyclase-cyclic AMP system (7).

The present studies examined effects of TSH on organification of iodide and thyroid hormone secretion during the refractory period.

\section{METHODS}

Beef, dog, and human thyroid tissues were obtained, sliced and incubated as reported (1). Normal human thyroid tissue was obtained at surgery from patients with benign, "cold" nodules. Each experiment was repeated at least three times. Three sequential incubations were done in a Dubnoff metabolic shaker at $37^{\circ} \mathrm{C}$ in $2 \mathrm{ml}$ of Krebs-Ringer bicarbonate or phosphate buffer containing $1 \mathrm{mg} / \mathrm{ml}$ glucose. The gas phase was $95 \% \mathrm{O}_{2}$ and $5 \% \mathrm{CO}_{2}$ when bicarbonate buffer was used and air when phosphate buffer was employed. The first incubation was done with and without TSH. The amount of TSH is

${ }^{1}$ Abbreviations used in this paper: DBC, dibutyryl cyclic AMP; PGE $_{1}$, prostaglandin $\mathrm{E}_{1}$; $\mathrm{T}_{4}, l$-thyroxine; $\mathrm{T}_{3}, l$-triiodothyronine; $\mathrm{TSH}$, thyrotropin. 
indicated in the figures or table. Between the incubations, slices were rinsed in $30 \mathrm{ml}$ of $0.85 \%$ saline and blotted on filter paper. During the second incubation all the slices were incubated in buffer. Half of the control slices that were not incubated with TSH during the first incubation were incubated in buffer alone during the third incubation. The other half were exposed to TSH for the first time in the third incubation. Half of the slices exposed to TSH in the initial incubation were incubated in buffer in the third incubation while the other half were re-exposed to the hormone.

Organification of iodide was studied as follows. Before the three sequential incubations, the thyroid slices were incubated for $1 \mathrm{~h}$ in $5 \mathrm{ml}$ of Krebs-Ringer phosphate buffer. The first incubation of the three sequential incubations was for $1 \mathrm{~h}$. The Krebs-Ringer phosphate buffer also contained $1 \mathrm{mg} / \mathrm{ml}$ bovine albumin and, where appropriate, $50 \mathrm{mU} / \mathrm{ml}$ TSH unless specified otherwise. The second incubation was also for $1 \mathrm{~h}$, but albumin was omitted from the buffer. The final incubation was for $30 \mathrm{~min}$ and the buffer contained $1 \mathrm{mg} / \mathrm{ml}$ albumin, $1 \mu \mathrm{g} / \mathrm{ml}$ of iodide, and $1.25 \mu \mathrm{Ci}{ }^{125} \mathrm{I}$. TSH $(50 \mathrm{mU} / \mathrm{ml}), \mathrm{DBC}$ $(1 \mathrm{mM})$ and prostaglandin $(\mathrm{PG}) \mathrm{E}_{1}(0.03 \mathrm{mM})$ were also present in the appropriate flasks during the third incubation. After the final incubation, organification of iodide was determined by the method of Ahn and Rosenberg (8).

The effects of $l$-triiodothyronine $\left(\mathrm{T}_{3}\right), l$-thyroxine $\left(\mathrm{T}_{4}\right)$, and iodide on the development of refractoriness were studied as follows. $\mathrm{T}_{3}$ or $\mathrm{T}_{4}(0.1 \mu \mathrm{M})$ or iodide $(1.5 \mu \mathrm{M}$ or $1 \mathrm{mM})$ was present during all three incubations. In the third incubation TSH was added for the first time to some of the slices that had previously been incubated with $\mathrm{T}_{3}, \mathrm{~T}_{4}$, or iodide. If any of these substances are responsible for refractoriness, the effect of TSH, added for the first time in the third incubation, should be diminished compared to slices incubated with only buffer in the first two incubations before the addition of TSH in the final incubation. The effect of propylthiouracil ( $1 \mathrm{mM}$ ) on the development of refractoriness was examined by incubating some of the slices with this compound for 15 min before and during the first incubation. After the second incubation the slices were incubated with and without TSH in the third incubation.

The role of protein synthesis in development of refractoriness was examined by incubating thyroid slices with and without puromycin $(150 \mu \mathrm{g} / \mathrm{ml})$ for $15 \mathrm{~min}$ before the first incubation. During the three subsequent incubations puromycin was again present in the appropriate flasks.

Stimulation of colloid droplet formation by TSH was investigated as follows. The initial incubation of thyroid slices was for $2 \mathrm{~h}$ in Krebs-Ringer bicarbonate buffer containing $1 \mathrm{mg} / \mathrm{ml}$ albumin and $2 \mathrm{mU} / \mathrm{ml} \mathrm{TSH}$ where appropriate. The second incubation in Krebs-Ringer bicarbonate was for $5 \mathrm{~h}$. Preliminary experiments demonstrated that after this length of time most of the increased colloid droplet formation resulting from the exposure to TSH in the first incubation had disappeared. The final incubation was for $2 \mathrm{~h}$ in Krebs-Ringer bicarbonate buffer containing $1 \mathrm{mg} / \mathrm{ml}$ albumin and, where appropriate, $2 \mathrm{mU} / \mathrm{ml} \mathrm{TSH}$. After the third incubation the colloid droplet response was measured in quadruplicate as reported (9).

The in vivo effect of TSH on release of $\mathrm{T}_{3}$ was investigated in $400 \mathrm{~g}$ male Sprague-Dawley rats. After an initial blood sample was obtained for $T_{3}$ measurement by radioimmunoassay (10), five rats received saline and five received $1 \mathrm{UTSH}$ i.v. 3 and $8 \mathrm{~h}$ later, additional samples were obtained for $T_{3}$ measurement. At this point, a second injection of TSH (1 U) was administered to all rats and the final blood sample obtained $3 \mathrm{~h}$ later. Preliminary studies indicated that the peak $\mathrm{T}_{3}$ response occurred $2-3 \mathrm{~h}$ after $\mathrm{TSH}$ administration and that by $8 \mathrm{~h}$ the values had returned to base line.
Bovine TSH (NIH-B8, $3.5 \mathrm{U} / \mathrm{ml}$ ) was generously provided by the Hormone Distribution Program of the National Institute of Arthritis, Metabolism, and Digestive Diseases, Bethesda, Md. Dr. John Pike, the Upjohn Co., Kalamazoo, Mich, kindly donated the $\mathrm{PGE}_{1}$. DBC was purchased from the Sigma Chemical Co., St. Louis, Mo. The sources of puromycin, propylthiouracil, $T_{3}$, and $T_{4}$ have been reported (1).

\section{RESULTS}

Prior incubation of dog thyroid slices with TSH (50 $\mathrm{mU} / \mathrm{ml}$ ) completely inhibited the subsequent stimulatory effect of this amount of TSH on organification of iodide (Fig. 1). In this experiment, the basal organification measured in the third incubation was not significantly influenced by the incubation of slices with TSH during the first incubation. Both DBC ( $1 \mathrm{mM})$ and $\mathrm{PGE}_{1}$ $(0.03 \mathrm{mM})$ significantly augmented organification of iodide although the effect was not as great as that induced by TSH. Initial incubation of dog thyroid slices with TSH also inhibited the effect of DBC and PGE ${ }_{1}$. Similar refractoriness to TSH stimulation of organification of iodide induced by an initial incubation with TSH was observed in beef and human thyroid slices (Fig. 2). Refractoriness of iodide organification in beef thyroid slices was also induced by $12.5 \mathrm{mU} / \mathrm{ml} \mathrm{TSH}$ and this was not overcome by increasing the amount of TSH to $50 \mathrm{mU} / \mathrm{ml}$ in the third incubation (Table I).
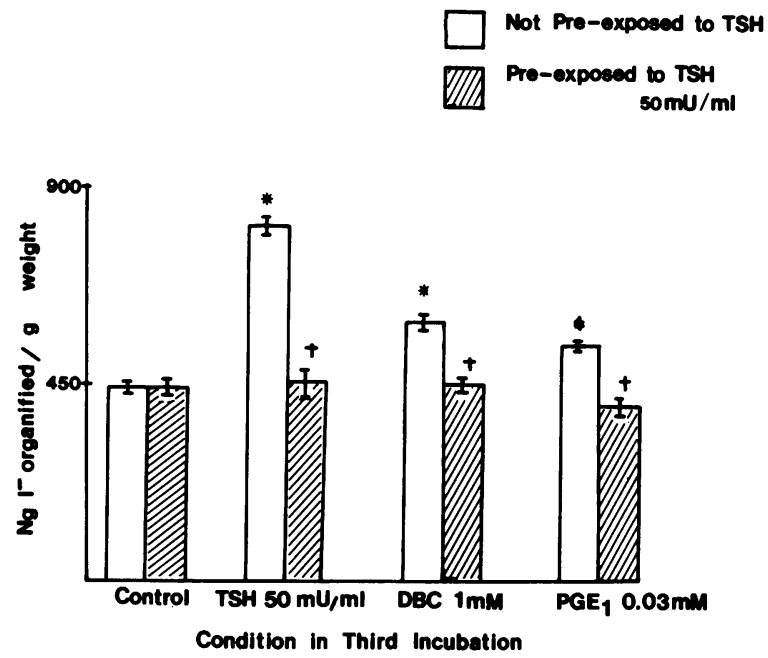

FIGURE 1 Effect of TSH, DBC, and $\mathrm{PGE}_{1}$ on organification of iodide in dog thyroid slices previously incubated with and without $50 \mathrm{mU} / \mathrm{ml}$ TSH. Dog thyroid slices $(20-40 \mathrm{mg}$ ) were incubated with and without TSH for $1 \mathrm{~h}$. After thorough rinsing they were then incubated for another hour in the absence of hormone. After washing, the slices were incubated for $30 \mathrm{~min}$ with the test substances as indicated. The buffer also contained $1 \mu \mathrm{g} / \mathrm{ml}$ iodide and $1.25 \mu \mathrm{Ci}{ }^{125} \mathrm{I}$. The results are the mean $\pm S E M$ of triplicate slices. $* P<0.01$ when compared to control slices not previously exposed to TSH. $(\dagger) P<0.01$ when compared to slices incubated with the same substance in the third incubation but not incubated with TSH in the first incubation. 


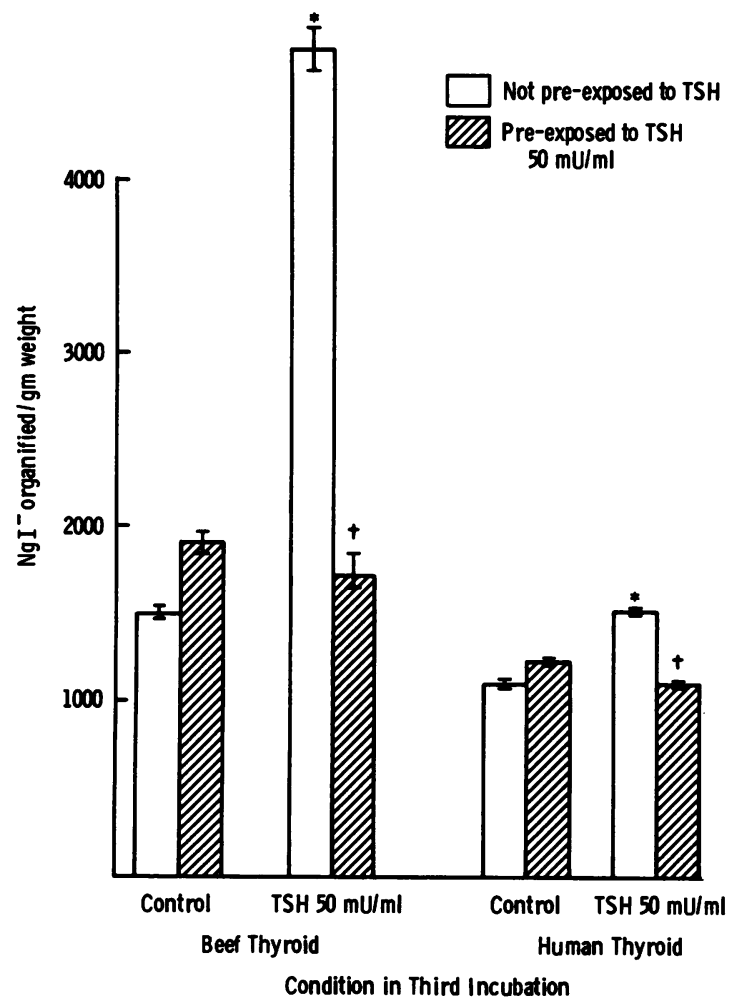

FIGURE 2 Effect of TSH on organification of iodide in beef and human thyroid slices previously incubated with and without $50 \mathrm{mU} / \mathrm{ml}$ TSH. Slices weighing between 30 and $50 \mathrm{mg}$ were incubated as indicated in the legend to Fig. 1. The results are the mean \pm SEM of triplicate slices. $\left(^{*}\right) P<0.01$ when compared to control slices not previously exposed to TSH. $(t) P<0.01$ when compared to slices incubated with the same substance in the third incubation but not incubated with TSH in the first incubation.

Incubation of bovine thyroid slices with either $0.1 \mu \mathrm{M}$ $\mathrm{T}_{3}$ or $\mathrm{T}_{4}$ during all three incubations did not diminish the effect of TSH added for the first time during the third incubation on organification of iodide (Fig. 3). In this experiment, exposure of thyroid slices to TSH in the first incubation significantly diminished iodide organification during the third incubation when the slices were incubated with buffer alone. As indicated in Figs. 1 and 2 such an effect of TSH in the first incubation was not a constant finding. The presence of $T_{3}$ or $T_{4}$ in the incubations also decreased iodide organification in the third incubation in the absence of TSH. The initial exposure of bovine thyroid slices to TSH during the first incubation caused a diminished response when TSH was added again during the third incubation. Addition of $1 \mathrm{mM}$ iodide in all three incubations inhibited the stimulatory effect of TSH added for the first time in the third incubation (Fig. 4). This amount of iodide also diminished the organification of iodide during the third incubation in bovine slices incubated with buffer alone. However, it did not modify the re-
TABLE I

Effect of Submaximal Dose of TSH on Refractoriness of Organification of Iodide Induced by that Hormone

\begin{tabular}{|c|c|c|}
\hline \multicolumn{2}{|c|}{ Incubations } & \multirow[b]{2}{*}{ Iodide organification } \\
\hline First & Third & \\
\hline \multicolumn{2}{|c|}{$\mathrm{TSH} \mathrm{mU} / \mathrm{ml}$} & $\mathrm{Ng} \mathrm{I}^{-} \lg$ wet $w t$ \\
\hline None & None & $982 \pm 23$ \\
\hline None & 12.5 & $1,326 \pm 87^{*}$ \\
\hline None & 50 & $1,751 \pm 31 \ddagger$ \\
\hline 12.5 & None & $894 \pm 28$ \\
\hline 12.5 & 12.5 & $979 \pm 96 \S$ \\
\hline 12.5 & 50 & $878 \pm 43^{\prime \prime}$ \\
\hline 50 & None & $1,040 \pm 41$ \\
\hline 50 & 12.5 & $939 \pm 23$ \\
\hline 50 & 50 & $1,008 \pm 47^{\prime \prime}$ \\
\hline
\end{tabular}

Beef thyroid slices were first incubated for $60 \mathrm{~min}$ in buffer alone or with 12.5 or $50 \mathrm{mU} / \mathrm{ml} \mathrm{TSH}$. The second incubation, in buffer alone, was $120 \mathrm{~min}$. The third incubation of $30 \mathrm{~min}$ was performed as follows: slices from each of the three groups in the first incubation were incubated in buffer alone or with 12.5 or $50 \mathrm{mU} / \mathrm{ml} \mathrm{TSH}$. The values represent the mean \pm SEM of triplicate slices.

$* P<0.02$ when compared to slices never exposed to TSH. $\ddagger P<0.01$ when compared to slices never exposed to TSH. $\S P<0.05$ when compared to slices first exposed to $12.5 \mathrm{mU} / \mathrm{ml}$ of TSH in the third incubation.

" $P<0.01$ when compaed to slices first exposed to 50 $\mathrm{mU} / \mathrm{ml}$ of TSH in the third incubation.

II $P<0.02$ when compared to slices first exposed to $12.5 \mathrm{mU} / \mathrm{ml}$ of TSH in the third incubation.

fractoriness induced by TSH. When a similar amount of iodide $(1.5 \mu \mathrm{M})$ was used in all three incubations, it also reduced iodide organification in slices initially incubated with buffer but not in slices exposed to TSH in the first incubation (Fig. 5). This smaller amount of iodide did not inhibit the stimulatory effect of TSH added for the first time in the third incubation. Refractoriness induced by TSH was also not influenced by this concentration of iodide. Incubation of dog thyroid slices with $1 \mathrm{mM}$ prophylthiouracil did not prevent refractoriness that developed from exposure of thyroid slices to TSH during the initial incubation (Fig. 6). The effect of inhibition of protein synthesis on the TSH-induced refractoriness was examined by including puromycin $(150 \mu \mathrm{g} / \mathrm{ml})$ in all three incubations. The data in Fig. 7 indicate that puromycin did not significantly modify the refractoriness induced by prior exposure to TSH.

Stimulation of colloid droplet formation induced by TSH was also diminished during the refractory period. Colloid droplet formation in bovine thyroid slices was increased from $0.04 \pm 0.02$ droplets/nucleus to $2.2 \pm 0.14$ 


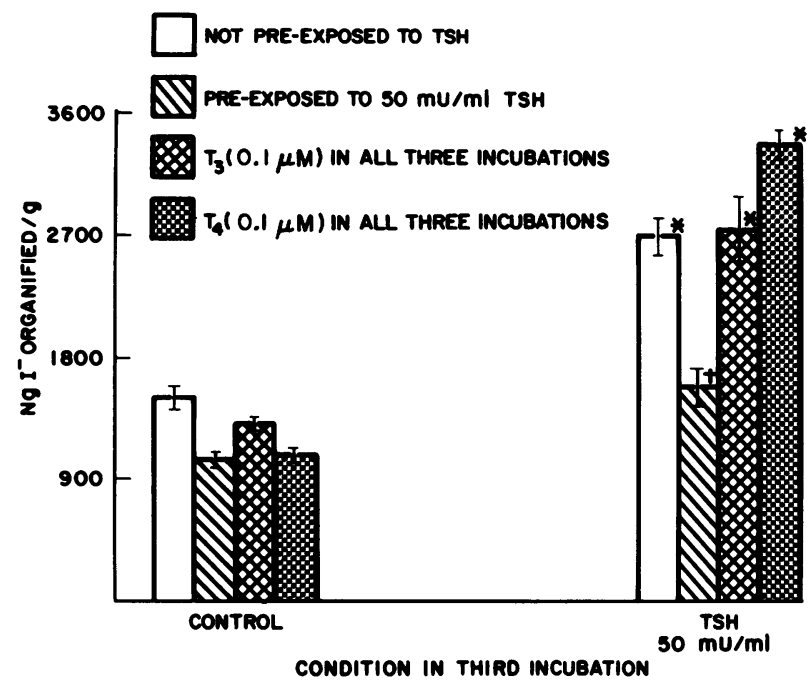

Figure 3 Effect of $\mathrm{T}_{3}$ and $\mathrm{T}_{4}$ on subsequent stimulation of organification of iodide by $\mathrm{TSH}$ in bovine thyroid slices. Bovine thyroid slices (30-50 mg) were incubated with buffer, $\mathrm{T}_{3}(0.1 \mu \mathrm{M}), \mathrm{T}_{4}(0.1 \mu \mathrm{M})$, or $\mathrm{TSH}(50 \mathrm{mU} / \mathrm{ml})$ for $1 \mathrm{~h}$. After thorough rinsing they were incubated for another hour with or without $T_{3}$ or $T_{4}$ as appropriate. In some slices $T_{3}$ or $T_{4}$ were also included in the third incubation of $30 \mathrm{~min}$. During this incubation appropriate slices were incubated with either buffer or TSH $(50 \mathrm{mU} / \mathrm{ml})$. The results are the mean \pm SEM of triplicate slices. $\left({ }^{*}\right) P<0.01$ when compared to the corresponding slices incubated with buffer in the third incubation. $(t) P<0.01$ when compared to slices that were not incubated with TSH in the first incubation but exposed to the hormone during the third incubation.

when $2 \mathrm{mU} / \mathrm{ml} \mathrm{TSH}$ was added for the first time during the third incubation. However, when slices were incubated with this amount of TSH in the first incubation, the subsequent addition of $2 \mathrm{mU} / \mathrm{ml}$ TSH increased colloid droplet formation from $0.09 \pm 0.04$ to $1.4 \pm 0.08$ droplets/nucleus. This effect was significantly less $(P$ $<0.01)$ than that obtained in slices incubated with TSH only in the third incubation. In addition to the in vitro demonstration of refractoriness of iodide metabolism to TSH, such desensitization was also found in vivo. The basal value of $T_{3}$ in a group of five rats was $46 \pm 5$ $\mathrm{ng} / 100 \mathrm{ml}$ and was unchanged $8 \mathrm{~h}$ after the intravenous injection of saline. The rats were then given $1 \mathrm{U} \mathrm{TSH}$ i.v. and $3 \mathrm{~h}$ later the $\mathrm{T}_{3}$ had increased by $29 \pm 3 \mathrm{ng} / 100 \mathrm{ml}$. In a second group of five rats, the $T_{3}$ value was $53 \pm 2$ $\mathrm{ng} / 100 \mathrm{ml} 8 \mathrm{~h}$ after $1 \mathrm{U}$ TSH i.v., not significantly different than the value after saline. $3 \mathrm{~h}$ after the second injection of TSH $(1 \mathrm{U})$ the $\mathrm{T}_{3}$ increased $15 \pm 5 \mathrm{ng} / 100 \mathrm{ml}$. This increase was significantly less $(P<0.05)$ than the increase induced by injection of TSH in the rats who received saline first.

\section{DISCUSSION}

The present results extend the observations that initial incubation of thyroid slices with TSH induces dimin-

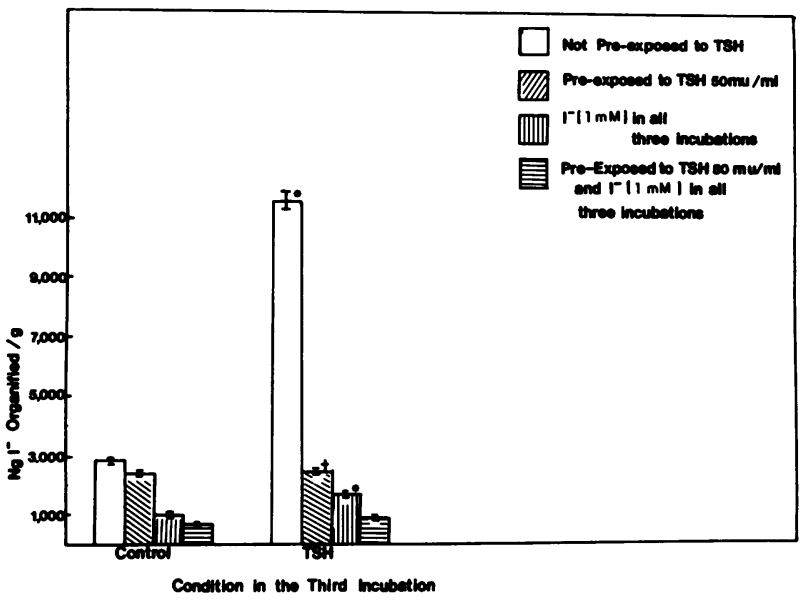

FIGURE 4 Effect of $1 \mathrm{mM}$ iodide on subsequent stimulation of organification of iodide by TSH in bovine thyroid slices. Bovine thyroid slices $(30-50 \mathrm{mg})$ were incubated with buffer, $1 \mathrm{mM}$ iodide, or TSH $(50 \mathrm{mU} / \mathrm{ml})$ for $1 \mathrm{~h}$. After thorough rinsing they were incubated for another hour with or without $1 \mathrm{mM}$ iodide as appropriate. In some slices $1 \mathrm{mM}$ iodide was also included in the third incubation. In the third incubation, slices were incubated with or without TSH $(50 \mathrm{mU} / \mathrm{ml})$. The results are the mean $\pm S E M$ of triplicate slices. $\left.{ }^{*}\right) P<0.01$ when compared to the corresponding slices incubated with buffer in the third incubation. $(\dagger) P<0.01$ when compared to slices that were not incubated with TSH in the first incubation but exposed to the hormone during the third incubation.

ished responsiveness to the subsequent addition of the hormone $(1,3,5,6)$. These studies demonstrated decreased stimulation of the adenylate cyclase-cyclic AMP system $(1,3,5)$ protein kinase, glucose oxidation and ${ }^{32} \mathrm{P}_{\mathrm{i}}$ incorporation into phospholipids (6) during the refractory period. The current studies indicate that

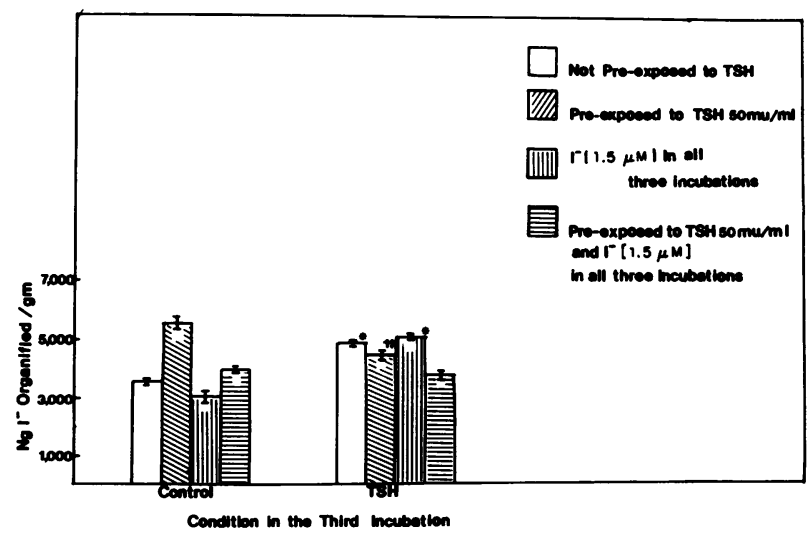

FIgURE 5 Effect of $1.5 \mu \mathrm{M}$ iodide on subsequent stimulation of organification of iodide by TSH in bovine thyroid slices. Experimental conditions as described for Fig. 4. $\left({ }^{*}\right) P<0.01$ when compared to the corresponding slices incubated with buffer in the third incubation. $(\dagger) P<0.02$ when compared to slices which were not incubated with TSH in the first incubation but exposed to the hormone during the third incubation. 


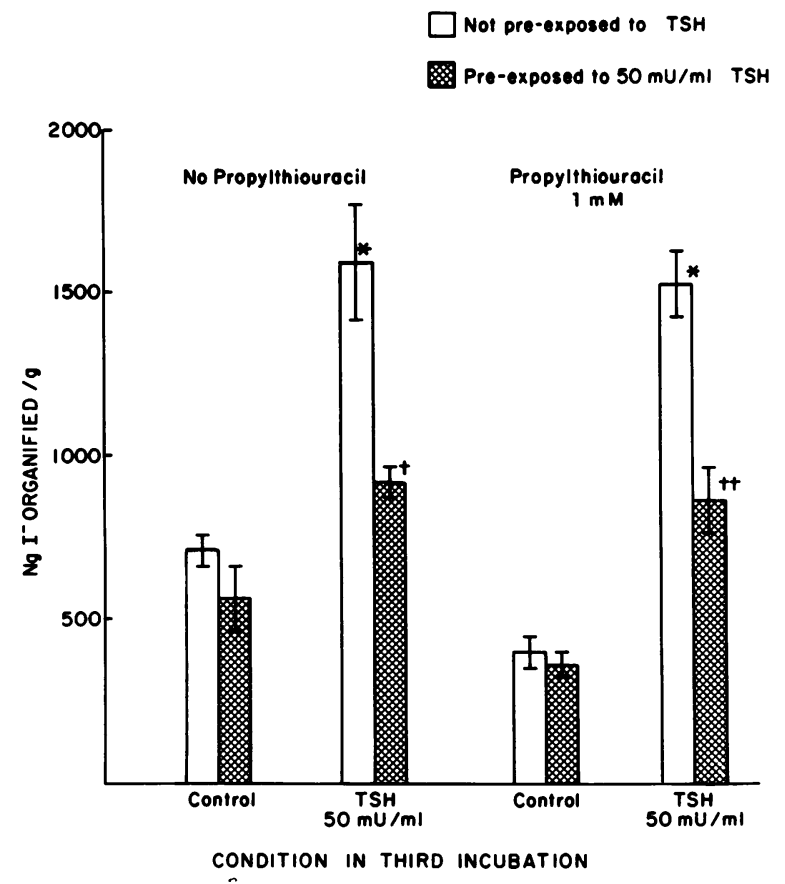

FIGURE 6 Effect of propylthiouracil on stimulation of organification of iodide by TSH in dog thyroid slices previously incubated with and without $50 \mathrm{mU} / \mathrm{ml} \mathrm{TSH}$. Slices weighing between 10 and $30 \mathrm{mg}$ were incubated with or without $1 \mathrm{mM}$ propylthiouracil for $\mathbf{1 5} \mathrm{min}$ before and during the first incubation. TSH was present in the appropriate flasks. The subsequent incubations were as indicated in the legend to Fig. 1. The results are the mean \pm SEM of triplicate slices. $\left({ }^{*}\right) P<0.01$ when compared to slices incubated with TSH during the third but not the first incubation. $(\dagger) P<0.05$ when compared to slices incubated with the same substance in the third incubation but not incubated with TSH in the first incubation. $(t+) P<0.02$ when compared to slices incubated with the same substance in the third incubation but not incubated with TSH in the first incubation.

such refractoriness includes effects of TSH on several aspects of thyroid hormone synthesis and secretion. Although the effects of TSH on iodide metabolism in the thyroid probably involve the adenylate cyclasecyclic AMP system (8), unresponsiveness of that system cannot completely explain the results obtained when organification of iodide was examined. Thus, DBC and $\mathrm{PGE}_{1}$ stimulation of this parameter were also inhibited in slices previously exposed to TSH. Addition of DBC should circumvent any reduction in cyclic AMP concentrations, and during the refractory period induced by TSH, PGE $_{1}$ stimulation of cyclic AMP was undiminished (1). These results support our previous conclusion that metabolic events after the generation of cyclic AMP are involved in the development of refractoriness (6).

The in vivo demonstration of refractoriness to TSH measuring serum $T_{3}$ is consistent with the in vitro observations on colloid droplet stimulation by TSH. The smaller rise in $\mathrm{T}_{3}$ after the second injection of TSH

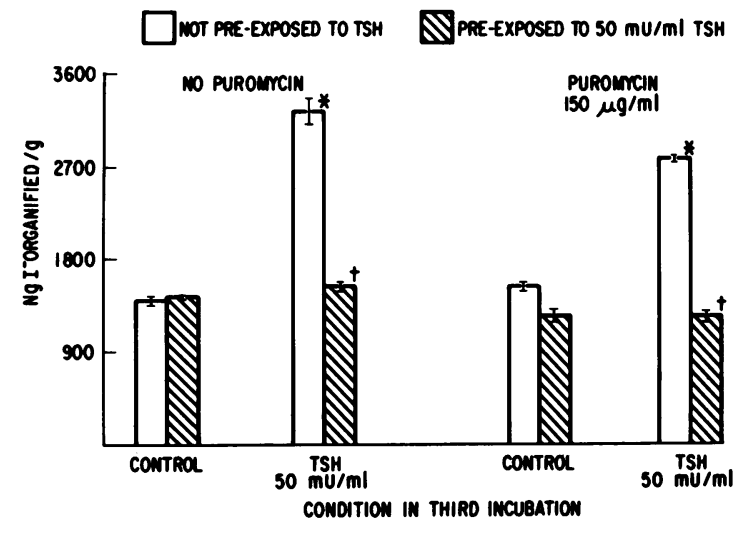

FIGURE 7 Effect of incubation of bovine thyroid slices with puromycin on TSH-induced refractoriness of organification of iodide. Puromycin $(150 \mu \mathrm{g} / \mathrm{ml})$ was present in all three incubations where appropriate. The results are the mean $\pm S E M$ of triplicate determinations. $\left({ }^{*}\right) P<0.01$ when compared to appropriate slices not exposed to TSH during the first incubation. $(\dagger) P<0.01$ when compared to slices incubated with TSH during the third but not the first incubation.

probably does not reflect depletion of thyroid stores of the hormone. The thyroid gland of these rats should contain $\cong 0.3 \mu \mathrm{g}$ of $\mathrm{T}_{3}(11)$ so the $29 \mathrm{ng} / 100 \mathrm{ml}$ increase after the initial TSH injection represents only $\cong 20 \%$ of the glandular content, assuming a space of distribution of $50 \%$ of body weight. Bjorkman et al. (12) also reported in vivo refractoriness to TSH since a second injection of the hormone into rats had a diminished effect of exocytic vesicles and iodination when it was given $2-4 \mathrm{~h}$ after the initial administration of TSH. In those studies an initial administration of TSH also rendered the thyroid unresponsive to stimulation by isoproterenol and cyclic AMP, indicating that the defect was subsequent to the generation of the cyclic nucleotide.

These in vivo results indicate that the refractory phenomenon could be of physiologic importance in regulating thyroid gland responsiveness to TSH. However, such refractoriness probably is not complete as it is well known that thyroid tissue continues to grow during continual stimulation by TSH. Several factors may account for this apparent discrepancy. Sherwin and Tong (4) suggested that TSH stimulation of $\alpha$-aminoisobutyrate accumulation and protein synthesis were not modified during the refractory period. In addition, the refractory period has a finite duration. Kaneko (3) reported that return of maximum TSH responsiveness required at least $6 \mathrm{~h}$ when cyclic AMP responses in cultured thyroid cells were investigated. A much longer interval $(24 \mathrm{~h})$ for recovery of TSH responsiveness was reported by Rapoport and Adams (5) when they measured cyclic AMP in cultured thyroid cells. Our previous studies indicated that a second incubation of $5 \mathrm{~h}$ was insufficient to reverse the refractory period (1). The interval between the initial and the subsequent admin- 
istration of TSH was $5 \mathrm{~h}$ in the colloid droplet studies and $8 \mathrm{~h}$ in the in vivo experiments. These times were purposely selected to minimize the effect of the initial exposure to TSH before the readdition of the hormone. It is possible that the failure to demonstrate more complete inhibition of the effect of TSH on $\mathrm{T}_{3}$ release in vivo is related to the 8 - $h$ interval between the two injections of the hormone. Bjorkman et al. (12) observed no refractoriness to TSH when the injections were $8 \mathrm{~h}$ apart and exocytic vesicles were measured.

The mechanisms involved in the induction of refractoriness are not known. As mentioned previously, diminished adenylate cyclase activity during the refractory period cannot adequately explain the lack of effects of TSH on iodide metabolism and glucose oxidation. Release of $\mathrm{T}_{4}, \mathrm{~T}_{3}$, or iodide induced by $\mathrm{TSH}$ might contribute to the refractoriness related to organification of iodide. Such a short-loop feedback system has been reported both in vivo and in vitro (13-15) but has also been denied in vivo (16). In the present experiments, thyroid hormones did not diminish the TSH stimulation of organification of iodide (Fig. 3). Although the amount of $T_{3}$ and $T_{4}$ used in the present experiments was less than that which inhibited cyclic AMP generation in the in vitro experiments of Yu et al (13), the concentration used in the present experiments is still supraphysiologic and is similar to what we have used previously ( 1 ). In the latter experiments $\mathrm{T}_{3}$ and $\mathrm{T}_{4}$ did not modify the effect of TSH on generation of cyclic AMP.

The relationship of iodide to the refractoriness may be more complex. Iodides have been reported to inhibit the TSH stimulation of organification of iodide, colloid droplet formation, and stimulation of cyclic AMP (4, 17-19). The possibility that iodide release induced by TSH during the first incubation inhibits the response to the hormone in the third incubation is unlikely for a variety of reasons. An initial incubation of thyroid slices with $1 \mathrm{mM}$ propylthiouracil did not prevent the induction of refractoriness by TSH. Propylthiouracil would prevent organification of iodide, and the inhibitory effects of iodide depend upon its organification as they were abolished by either Tapazole (Eli Lilly \& Co., Indianapolis, Ind.) or propylthiouracil $(4,18,19)$. Furthermore, the slices were thoroughly washed and incubated in fresh medium after exposure to TSH during the initial incubation. For similar reasons, we concluded that iodides were probably not important in the development of the refractoriness of the TSH stimulation of cyclic AMP (1). Furthermore, $1.5 \mu \mathrm{M}$ iodide in the first and second incubations did not inhibit TSH stimulation of organification of iodide in the third incubation (Fig. 5). Although $1 \mathrm{mM}$ iodide did diminish TSH stimulation of iodide organification (Fig. 4), it is unlikely that such concentrations of inorganic iodide would be generated by an initial incubation with TSH (11), especially because the slices were thoroughly washed and incubated in fresh buffer between incubations. Gross and Gafni (17) reported the effects of iodide on TSH stimulation of iodide metabolism are complex and dose dependent. High doses of iodide $(1-10 \mu \mathrm{g})$ inhibited the effect of TSH on colloid droplet formation and $\mathrm{T}_{4}$ and $\mathrm{T}_{3}$ release, while $0.2 \mu \mathrm{g} \mathrm{KI}$ actually potentiated the action of TSH. The complexity is further emphasized by their observation that $0.2 \mu \mathrm{g}$ KI either augmented or inhibited TSH stimulation of cyclic AMP depending upon whether the response to TSH, alone, was low or high.

In accord with our previous findings (1), puromycin did not inhibit the TSH-induced refractoriness when organification of iodide was assessed. This provides further evidence that new protein synthesis is not essential for this phenomenon. The failure of $50 \mathrm{mU} / \mathrm{ml}$ TSH to overcome the refractoriness induced by 12.5 $\mathrm{mU} / \mathrm{ml}$ of TSH is similar to the results that we have previously reported when generation of cyclic AMP was examined (1). Although $12.5 \mathrm{mU} / \mathrm{ml}$ TSH was a submaximal dose when organification of iodide was measured, it is a maximal amount of hormone for the generation of cyclic AMP (20). If the effect that is responsible for induction of refractoriness is also maximal at this concentration of $\mathrm{TSH}$, it is not surprising that it was not modified by the larger amount of TSH.

\section{ACKNOWLEDGMENTS}

We would like to thank Ms. Kay Specter for invaluable help in preparing the figures, and Ms. Susan Gehring and Ms. Suzette Ashworth for their expert preparation of the manuscript.

This work was supported by U. S. Public Health Service grants AM 06865 and AM 26088.

\section{REFERENCES}

1. Shuman, S. J., U. Zor, R. Chayoth, and J. B. Field. 1976. Exposure of thyroid slices to thyroid-stimulating hormone induces refractoriness of the cyclic AMP system to subsequent hormone stimulation. J. Clin. Invest. 57: 1132-1141.

2. Verrier, B., and H. L. Cailla. 1976. Endogenous cyclic AMP in thyroid cell culture. Effect of thyroid stimulating hormone and dibutyryl cyclic AMP. Biochem. Biophys. Acta. 428: 233-239.

3. Kaneko, Y. 1976. Cyclic AMP level of human thyroid cells in monolayer culture. TSH induced refractoriness to TSH action. Horm. Metab. Res. 8: 202-206.

4. Sherwin, J. R., and W. Tong. 1975. Thyroidal autoregulation. Iodide-induced suppression of thyrotropin-stimulated cyclic AMP production and iodinating activity in thyroid cells. Biochem. Biophys. Acta. 404: 30-39.

5. Rapoport, B., and R. J. Adams. 1976. Induction of refractoriness to thyrotropin stimulation in cultured thyroid cells. Dependence on new protein synthesis. J. Biol. Chem. 251: 6653-6661.

6. Field, J. B., G. Bloom, C. Y. Chou, and M. E. Kerins. 1977. Inhibition of thyroid-stimulating hormone stimulation of protein kinase, glucose oxidation, and phospho- 
lipid synthesis in thyroid slices previously exposed to the hormone. J. Clin. Invest. 59: 659-665.

7. Kaneko, T., U. Zor, and J. B. Field. 1969. Thyroid stimulating hormone and prostaglandin $E_{1}$ stimulation of cyclic $3^{\prime} 5^{\prime}$ AMP in thyroid slices. Science (Wash. D. C.) 163: $1062-1063$.

8. Ahn, C. S., and I. N. Rosenberg. 1970. Iodine metabolism in thyroid slices: effects of TSH, dibutyryl cyclic $3^{\prime}, 5^{\prime}$ $\mathrm{AMP}, \mathrm{NaF}$, and prostaglandin $\mathrm{E}_{1}$. Endocrinology. 86: 396-405.

9. Dekker, A., and J. B. Field. 1970. Correlation of effects of thyrotropin, prostaglandins and ions on glucose oxidation, cyclic AMP, and colloid droplet formation in dog thyroid slices. Metab. Clin. Exp. 19: 453-464.

10. Larsen, P. R. 1972. Direct immunoassay of triiodothyronine in human serum. J. Clin. Invest. 51: 1939-1949.

11. Riesco, G., A. Taurog, P. R. Larsen, and L. Krulich. 1977. Acute and chronic responses to iodine deficiency in rats. Endocrinology. 100: 303-313.

12. Bjorkman, U., R. Ekholm, and L. E. Ericson. 1978. Effects of thyrotropin on thyroglobulin exocytosis and iodination in the rat thyroid gland. Endocrinology. 102: 460-470.

13. Yu, S., Y. Friedman, R. Richman, and G. Burke. 1976. Altered thyroidal responsivity to thyrotropin induced by circulating thyroid hormones.J. Clin. Invest. 57: 745-755.

14. Friedman, Y., M. Lang, and G. Burke. 1977. Inhibition of thyroid adenylate cyclase by thyroid hormone: a possible locus for the "short-loop" negative feedback phenomenon. Endocrinology. 101: 858-868.

15. Gafni, M., N. Sirkis and J. Gross. 1975. Inhibition of the response of mouse thyroid to thyrotropin induced by chronic triiodothyronine treatment. Endocrinology. 97: 1256-1262.

16. Croxson, M. S., T. D. Hall, and J. T. Nicoloff. 1977. Failure of triiodothyronine to inhibit TSH-mediated thyroid hormone release in man. J. Clin. Endocrinol. Metab. 45: 593-596.

17. Gross, J., and M. Gafni. 1976. Intrathyroidal mechanisms which modulate the action of TSH. In Biochemical Basis of Thyroid Stimulation and Thyroid Hormone Action. A. von zur Muhlen and H. Schleusener, editors. George Thieme Verlag KG, Stuttgart, 133-142.

18. Burke, G. 1970. Effects of iodide on thyroid stimulation. J. Clin. Endocrinol. Metab. 30: 76-84.

19. Van Sande, J., and J. E. Dumont. 1973. Effects of thyrotropin, prostaglandin $E_{1}$ and iodide on cyclic $3^{\prime}, 5^{\prime}$-AMP concentration in dog thyroid slices. Biochem. Biophys. Acta. 313: 320-328.

20. Field, J. B., G. Bloom, M. E. Kerins, R. Chayoth, and U. Zor. 1975. Activation of protein kinase in thyroid slices by thyroid-stimulating hormone. J. Biol. Chem. 250: 4903-4910. 